\title{
Thermally Compressed Poplar Wood (TCW): Physical and Mechanical Properties
}

\section{Toplinski prešano drvo topole (TCW): fizikalna i mehanička svojstva}

\author{
Preliminary paper • Prethodno priopćenje \\ Received-prispjelo: 28. 9. 2012. \\ Accepted-prihvaćeno: 15. 02. 2013. \\ UDK: $630 * 812 ; 674.812$ \\ doi:10.5552/drind.2013.1216
}

\begin{abstract}
Various thermal modification techniques are used to improve some properties of wood materials. Thermally compressed wood (TCW) is obtained by using a hot-press. This study investigates the effect of thermal compression on the density, vertical density profile (VDP), moisture content (MC), thickness swelling (TS), Janka hardness, and drying characteristics of the poplar wood boards. The experimental boards were cut from poplar wood (Populus spp). The boards with dimensions of $100 \mathrm{~mm}$ by $500 \mathrm{~mm}$ by $25 \mathrm{~mm}$ were thermally compressed at press temperature of either $150^{\circ} \mathrm{C}$ or $170^{\circ} \mathrm{C}$, press pressure of either 1 or $2 \mathrm{MPa}$ for 45 minutes in a hot-press. A total of 10 experimental boards were prepared - two boards for each group plus two for control. The results obtained in this study indicated that the density and Janka hardness values increased with the increase of the press pressure. The thermal compression process decreased the thickness of the boards. The thickness reduction increased with the increase of the press pressure. An improvement was not seen in the TS values of the samples when compared to those of the untreated samples. This study revealed that the thermal compression technique should be used to improve some properties of poplar wood. In this way better use could be made of low-cost poplar wood.
\end{abstract}

Keywords: Thermally compressed wood (TCW), hardness, vertical density profile, density, poplar wood (Populus spp)

SAŽETAK • Kako bi se poboljšala neka svojstva drva, primjenjuju se različite tehnike toplinske modifikacije. Toplinski prešano drvo (TCW) dobije se uz pomoć vruće prě̌e. U radu se prikazuje istraživanje učinka toplinske kompresije na gustoću drva, vertikalni profil gustoće (VDP), sadržaj vode (MC), bubrenje (TS) i tvrdoću prema Janki, kao i obilježja sušenja topolova drva. Uzorci za istraživanja izrađeni su od drva topole (Populus spp.). Ploče dimenzija $100 \mathrm{~mm} \times 500 \mathrm{~mm} \times 25 \mathrm{~mm}$ toplinski su prešane pri temperaturi 150 i $170{ }^{\circ} \mathrm{C}$ te pri tlaku 1 i 2 MPa tijekom 45 minuta u vrućoj preši. Uz jednake uvjete prešane su po dvije ploče, što s dvije kontrolne ploče ukupno iznosi deset uzoraka. Rezultati istraživanja pokazali su da se gustoća i tvrdoća prema Janki povećavaju s povećanjem tlaka prešanja. Toplinskim se prěsanjem smanjuje debljina ploča. Smanjenje debljine povećava se s povećanjem tlaka prešanja. Nije ustanovljeno smanjenje bubrenja toplinski prešanih ploča u odnosu prema kontrolnim uzorcima. Istraživanja su pokazala da se toplinskim prešanjem mogu poboljšati samo neka svojstva topolova drva. Na taj bi se način moglo bolje iskoristiti relativno jeftino drvo topolovih šuma.

Ključne riječi: toplinski prešano drvo (TCW), tvrdoća, vertikalni profil gustoća, gustoća, topolovo drvo (Populus spp.)

\footnotetext{
${ }^{1}$ Author is professors at Istanbul University, Faculty of Forestry, Department of Forest Products Engineering, Istanbul-Turkey. ${ }^{2}$ Author is professor at Duzce University, Faculty of Forestry, Department of Forest Products Engineering, Duzce-Turkey.

Autori su profesori Šumarskog fakulteta Sveučilišta u Istanbulu, Odjel za tehnologiju drvnih proizvoda, Istanbul, Turska. ${ }^{2}$ Autor je profesor

Šumarskog fakulteta Sveučilišta u Duzceu, Odjel za tehnologiju drvnih proizvoda, Duzce, Turska.
} 


\section{INTRODUCTION}

\section{UVOD}

Poplar wood (Populus spp) is one of the fast growing tree species in Turkey. It has some advantages such as wide availability, fast growing rate, and low cost. However, it also has some undesired properties such as low surface hardness because of its low density, low dimensional stability, and some drying problems.

It is known that thermal modification could improve dimensional stability, equilibrium moisture content, permeability, surface quality, and durability of wood materials (Burmester, 1973; Giebeler, 1983; Korkut and Kocaefe, 2009). There are various thermal treatment methods in Europe. This technology is registered in many European countries: France (Perdure, New Option wood, retifraction), Finland (Thermowood), Netherlands (Plato, Lignius, Lambowood), Danmark (Wood Treatment Technology - WTT)), Austria (Huber Holz), Germany (Menz Holz), Russia (Barkett), and Netherlands (Plato, Lignius, Lambowood) (Tjeerdsma, 2006). The main differences between the processes are to be seen in the process conditions, process steps, oxygen or nitrogen, steaming, wet or dry process, use of oils, steering schedules, etc. (Militz, 2002).

Thermally modified wood materials could be considered as an ecological alternative to impregnated wood material. It could also be used in the landscape architectural application, production of kitchen and outdoor furniture, sauna elements, building elements, flooring materials, ceilings, inner and outer bricks, doorwindow joinery, sun blinds, and noise barriers (Sevim Korkut et al., 2008; Korkut and Kocaefe, 2009).

The purpose of combining compression and temperature application on wood is to improve its physical and mechanical properties. Compressed wood is known as Staypak (Seborg et al., 1945; Stamm et al., 1964) while compressed wood with phenol formaldehyde (PF) resin pretreatment is called Compreg (Stamm, 1964; Stamm and Haris, 1953). Further studies were done by Tarkow and Seborg (1968) who investigated the surface densification of wood.

Compression in wood is generally considered to be analogous to hot pressing of wood composites, except that it takes longer to obtain solid wood compression without the bonding effect of resins. Wang and Cooper (2004) studied the effects of grain orientation and surface plasticizing methods on the VDPs of compressed balsam fir and spruce. In another study, Wand and Cooper (2005) studied the effects of hot press closing rate, wood initial moisture content, and sample size on the VDPs of thermally compressed fir wood. Density distribution through the thickness of wood composites, such as fiberboard and oriented strandboard, traditionally exhibits higher surface density and lower core density. Density gradient is affected by the combined influence of pressure, $\mathrm{MC}$, temperature, resin curing, and other factors during pressing and it affects physical and mechanical properties of wood composites (Strickler, 1959; Kamke and Casey, 1988; Wang and Winistorfer, 2000; Candan, 2007). Due to differ- ences in material properties and hot pressing parameters compared to wood composite production, densified wood boards could show a different density profile. Thermal compression process might affect drying characteristics, dimensional stability, density, Janka hardness, and surface quality.

Physical, mechanical, anatomical, durability, and surface properties of TCW have been studied in previous works by Wang et al. (2000), Wang and Cooper (2004), Wang and Cooper (2005), Unsal and Candan (2007), Unsal et al. (2008), Unsal and Candan (2008), Unsal et al. (2009), Candan et al. (2010), Dogu et al. (2010), Abraham et al. (2010), Unsal et al. (2011a), Unsal et al. (2011b), Candan et al. (2013).

The influence of press pressure and temperature on the vertical density profile, Janka hardness, and MC of pine wood was studied by Unsal and Candan (2008). It was stated that the final MC reduced while the density and Janka hardness increased. Unsal et al. (2009) performed thermal compression of pine wood boards. It was reported that the thickness swelling values of the boards improved except for the boards pressed at 7 $\mathrm{MPa}$ and $150^{\circ} \mathrm{C}$.

This study investigated Janka hardness, final MC, density, VDP, and thickness swelling properties of the poplar wood boards affected by thermal modification.

\section{MATERIALS AND METHODS}

\section{MATERIJALI I METODE}

\subsection{Materials}

2.1. Materijali

Poplar (Populus spp) wood was used in this study. Experimental wood boards with dimensions of $100 \mathrm{~mm}$ by $500 \mathrm{~mm}$ by $25 \mathrm{~mm}$ were cut from the logs.

The boards were compressed at a press temperature of either $150{ }^{\circ} \mathrm{C}$ or $170{ }^{\circ} \mathrm{C}$, and press pressure of either 1 or $2 \mathrm{MPa}$ for 45 minutes by using a laboratory type hot press. A total of ten experimental boards were prepared - two boards for each group plus two boards for the untreated group. The boards (A) were compressed at a press temperature of $150{ }^{\circ} \mathrm{C}$, and press pressure of $1 \mathrm{MPa}$ for 45 minutes. The boards (B) were compressed at a press temperature of $150{ }^{\circ} \mathrm{C}$, and press pressure of $2 \mathrm{MPa}$ for 45 minutes. The boards (C) were compressed at a press temperature of $170^{\circ} \mathrm{C}$, and press pressure of $1 \mathrm{MPa}$ for 45 minutes. The boards (D) were compressed at a press temperature of $170{ }^{\circ} \mathrm{C}$, and press pressure of $2 \mathrm{MPa}$ for 45 minutes.

\subsection{Method}

\subsection{Metoda}

Larger specimens $(100 \mathrm{~mm}$ "tangential by 500 $\mathrm{mm}$ longitudinal by final board thickness) were cut into $50 \mathrm{~mm}$ by $50 \mathrm{~mm}$ to perform tests. In this study, density and thickness swelling was performed according to international standards. VDPs were measured with an X-ray density profiler (GreCon Measurement Systems, Germany) at Kastamonu Integrated Inc. Test Laboratory located in Kocaeli, Turkey. Peak density (PD) and core density (CD) values were generated 
...... Candan, Korkut, Unsal: Thermally Compressed Poplar Wood (TCW): Physical and...

Table 1 Thickness swelling and water absorption values of TCW boards

Tablica 1. Rezultati mjerenja debljinskog bubrenja i upijanja vode uzoraka toplinski prešanog drva

\begin{tabular}{|l|c|c|c|c|}
\hline $\begin{array}{l}\text { Panel groups } \\
\text { Skupina uzoraka }\end{array}$ & $\begin{array}{c}\text { Thickness swelling } \\
\text { (TS), \% } \\
\text { Debljinsko bubrenje, \% }\end{array}$ & $\begin{array}{c}\text { Duncan's } \\
\text { grouping } \\
\text { Grupiranje } \\
\text { prema Duncanu }\end{array}$ & $\begin{array}{c}\text { Water absorption (WA), \% } \\
\text { Upijanje vode (WA), \% }\end{array}$ & $\begin{array}{c}\text { Duncan's } \\
\text { grouping } \\
\text { Grupiranje prema } \\
\text { Duncanu }\end{array}$ \\
\hline Control / kontrolna & $1.750(0.664)$ & $\mathrm{e}$ & $35.162(3.366)$ & $\mathrm{e}$ \\
\hline $\mathrm{A}\left(150^{\circ} \mathrm{C}+1 \mathrm{MPa}\right)$ & $2.334(0.867)$ & $\mathrm{de}$ & $42.182(7.333)$ & $\mathrm{acde}$ \\
\hline $\mathrm{B}\left(150^{\circ} \mathrm{C}+2 \mathrm{MPa}\right)$ & $5.991(1.207)$ & $\mathrm{acde}$ & $38.247(2.293)$ & $\mathrm{c}$ \\
\hline $\mathrm{C}\left(170^{\circ} \mathrm{C}+1 \mathrm{MPa}\right)$ & $2.380(0.395)$ & $\mathrm{ce}$ & $40.362(2.806)$ & $\mathrm{be}$ \\
\hline $\mathrm{D}\left(170^{\circ} \mathrm{C}+2 \mathrm{MPa}\right)$ & $5.632(1.228)$ & bcde & $37.235(6.462)$ & $\mathrm{d}$ \\
\hline
\end{tabular}

* Values in parentheses are standard deviation / vrijednosti u zagradama standardne su devijacije.

from the VDP graphs. PD indicates the mean value of the highest densities measured within each half of the density profile, while core density indicates the average density of the central region of the panel (Candan, 2007). Janka hardness test was performed according to ASTM D1037 (1999) standard using a universal test machine and its results were expressed in newtons. Before the thermal modification process, the initial MC values of the samples were measured to determine the drying behavior of the poplar boards. For this aim, TS 2471 (1976) was used. After the thermal modification, the average final MC values were also determined. To evaluate the results of the boards modified with hotpress, all multiple comparisons were first tested using an analysis of variance (one-way ANOVA) at $p<0.05$. Significant differences between the mean values of thermally modified groups and the control group were determined using Duncan's multiple range test.

\section{RESULTS AND DISCUSSION}

\section{REZULTATI I RASPRAVA}

\subsection{Thickness swelling and water absorption}

3.1. Bubrenje i upijanje vode

Among the modification groups, the poplar boards pressed at $1 \mathrm{MPa}$ had the lowest thickness swelling values after being soaked in water for 24 hours. The boards pressed at $2 \mathrm{MPa}$ and at the temperature of $150{ }^{\circ} \mathrm{C}$ showed the highest thickness swelling values (Table 1).

All thermally compressed poplar boards showed higher thickness swelling values than the control boards. This result might be explained by springback behavior of wood due to the densification during hotpressing. The thickness swelling values of the treated boards increased with the increase of press pressure. According to Abraham et al. (2010) the higher densification ratio resulted in higher springback, due to the memory effect of wood. The springback phenomenon is greatly controlled by the press pressure level. Higher press pressure level may cause greater springback. On the other hand, higher temperature resulted in higher permanent deformation. Improvement in TS with the increase of press temperature could be explained by changes in chemical composition of wood. Unsal et al. (2009) obtained similar results for pine wood to the results of this study. It was also stated that the thickness swelling values of the TCW significantly increased with the increase of press pressure.

The water absorption (WA) values of the unmodified poplar wood boards, after being soaked in water for 24 hours, were lower than those of the modified poplar wood boards. Among the modified groups, it was determined that the boards modified with press pressure of $1 \mathrm{MPa}$ at $150{ }^{\circ} \mathrm{C}$ had the highest WA values, while the boards modified with press pressure of 2 $\mathrm{MPa}$ at $170^{\circ} \mathrm{C}$ had the lowest values. The findings obtained from the WA tests show that the thermal compression procedure had a negative effect on WA properties. On the other hand, the WA values decreased as the press pressure or temperature increased.

\subsection{Moisture reduction during thermal compression}

3.2. Smanjenje sadržaja vode tijekom vrućeg prešanja

The initial MC values of the samples were around 15\%. All TCW groups had lower MC values than those of the untreated group. The TCW modified with $2 \mathrm{MPa}$ at $170{ }^{\circ} \mathrm{C}$ had the lowest MC values (Table 2).

According to the present study, it could be stated that the drying effect of thermal modification is remarkable. The results obtained in this study were in accordance with a previous study by Unsal and Candan (2008). They applied thermal compression technique on pine wood boards. It was reported that the thermal compression process had a significant effect on drying properties of wood boards. Esteves et al. (2007) used a steam heating process on eucalyptus wood and found that the equilibrium MC decreased by $61 \%$ while the dimensional stability increased.

Table 2 MC values of Poplar TCW

Tablica 2. Sadržaj vode toplinski prešanoga topolova drva

\begin{tabular}{|l|c|c|}
\hline $\begin{array}{l}\text { Panel groups } \\
\text { Skupine uzoraka }\end{array}$ & $\begin{array}{c}\text { MC values } \\
\text { Sadržaj vode, \% }\end{array}$ & $\begin{array}{c}\text { Duncan's grouping } \\
\text { Grupiranje prema } \\
\text { Duncanu }\end{array}$ \\
\hline Control/ kontrola & $14.93(0.505)$ & abcde \\
\hline A & $10.67(0.244$ & bcde \\
\hline B & $10.10(0.079)$ & d \\
\hline C & $10.27(0.166)$ & ce \\
\hline D & $9.97(0.120)$ & e \\
\hline
\end{tabular}

* Values in parentheses are standard deviation / vrijednosti u zagradama standardne su devijacije. 
Table 3 Mean density values of Poplar TCW

Tablica 3. Prosječna gustoća toplinski prešanoga topolova drva

\begin{tabular}{|c|c|c|}
\hline $\begin{array}{c}\text { Panel groups } \\
\text { Skupine uzoraka }\end{array}$ & $\begin{array}{c}\text { Density values } \\
\text { Gustoća } \\
\mathrm{g} / \mathrm{cm}^{3}\end{array}$ & $\begin{array}{c}\text { Duncan's grouping } \\
\text { Grupiranje prema } \\
\text { Duncanu }\end{array}$ \\
\hline $\begin{array}{c}\text { Control / } \\
\text { kontrolna }\end{array}$ & $0.387(0.027)$ & $\mathrm{c}$ \\
\hline $\mathrm{A}$ & $0.366(0.034)$ & $\mathrm{e}$ \\
\hline $\mathrm{B}$ & $0.417(0.013)$ & $\mathrm{bcde}$ \\
\hline $\mathrm{C}$ & $0.368(0.032)$ & $\mathrm{d}$ \\
\hline $\mathrm{D}$ & $0.455(0.054)$ & $\mathrm{abcde}$ \\
\hline
\end{tabular}

* Values in parentheses are standard deviation / vrijednosti u zagradama standardne su devijacije.

\subsection{Vertical density profile (VDP) and mean} density

3.3. Vertikalni profil gustoće (VDP) i prosječna gustoća

The results obtained in this study showed that the mean density values were affected by the thermal compression. No significant difference was observed between the density values of the TCWs modified with 1 $\mathrm{MPa}$ and the untreated wood boards. When the press pressure was increased from $1 \mathrm{MPa}$ to $2 \mathrm{MPa}$, the density values increased from 0.37 to $0.45 \mathrm{~g} / \mathrm{cm}^{3}$. The TCW modified with $2 \mathrm{MPa}$ at $170{ }^{\circ} \mathrm{C}$ had the highest density values (Table 3 ).

Peak density (PD) and core density (CD) values as vertical density profile (VDP) characteristics of the TCWs were affected by the modification. The control group had a PD value of $403 \mathrm{~kg} / \mathrm{m}^{3}$ and a CD value of $368 \mathrm{~kg} / \mathrm{m}^{3}$. The TCW modified with $2 \mathrm{MPa}$ had the highest $\mathrm{PD}$ and $\mathrm{CD}$ values. It was concluded that the modification increased the PD and CD values of poplar wood. Similar results were determined by Unsal and Candan (2008). It was reported that the PD values of the pine wood boards increased with the increase of press pressure. Unsal et al. (2011b) examined the effect of the thermal modification on overall density or VDP properties of the Eucalyptus wood boards. They established that the control group had the lowest PD value, while the boards modified at $150{ }^{\circ} \mathrm{C}$ and pressure of 60 bar had the highest value. It was also reported that the mean density and PD values of the boards increased as the hot-press pressure increased.

\subsection{Janka hardness}

3.4. Tvrdoće prema Janki

The Janka hardness values evaluated for the control and the modified poplar boards are shown in Table 4.

The unmodified group had the lowest Janka hardness value $(1563.86 \mathrm{~N})$, while the group $\mathrm{B}$ had the highest value $(2063.02 \mathrm{~N})$. When the press pressure was increased from $1 \mathrm{MPa}$ to $2 \mathrm{MPa}$ at $150{ }^{\circ} \mathrm{C}$, the hardness value increased from 1814.72 to $2063.02 \mathrm{~N}$. Similarly, when the pressure was increased from $1 \mathrm{MPa}$ to $2 \mathrm{MPa}$, the hardness value of the boards pressed at $170{ }^{\circ} \mathrm{C}$ increased from 1804.52 to $2041.45 \mathrm{~N}$. By using maximum pressure, hardness increased by approximately $32 \%$ as compared to the unmodified board. The
Table 4 Janka Hardness of Poplar TCW

Tablica 4. Tvrdoća prema Janki toplinski prešanoga topolova drva

\begin{tabular}{|c|c|c|}
\hline $\begin{array}{c}\text { Panel groups } \\
\text { Skupine } \\
\text { uzoraka }\end{array}$ & $\begin{array}{c}\text { Janka hardness, N } \\
\text { Tvrdoća prema } \\
\text { Janki, N }\end{array}$ & $\begin{array}{c}\text { Duncan's grouping } \\
\text { Grupiranje prema } \\
\text { Duncanu }\end{array}$ \\
\hline $\begin{array}{c}\text { Control } \\
\text { kontrolna }\end{array}$ & $1563.86(181.71)$ & $\mathrm{e}$ \\
\hline $\mathrm{A}$ & $1814.72(316.36)$ & $\mathrm{c}$ \\
\hline $\mathrm{B}$ & $2063.02(359.02)$ & $\mathrm{ae}$ \\
\hline $\mathrm{C}$ & $1804.52(347.84)$ & $\mathrm{d}$ \\
\hline $\mathrm{D}$ & $2041.45(375.59)$ & $\mathrm{be}$ \\
\hline
\end{tabular}

* Values in parentheses are standard deviation/vrijednosti u zagradama standardne su devijacije.

improvement in the Janka hardness values could be attributed to an increase in density values. The hardness values of the TCW groups were higher than those of the untreated group. The results obtained in this study revealed that the hardness of the poplar boards was improved by the thermal compression. The hot-press temperature had no significant impact on the hardness values of the boards in the applied range. According to the study of Abraham et al. (2010), an elevated temperature $\left(200{ }^{\circ} \mathrm{C}\right)$ resulted in significantly higher BrinellMörath hardness values. The results of a previous study by Unsal and Candan (2008) were similar to the results of the present study. It was reported that the hardness values improved as the press pressure increased.

\section{CONCLUSIONS}

\section{ZAKLJUČCI}

The thermal modification process could not generate an improvement in the thickness swelling property of the boards. The density values of the boards increased as the press pressure increased. It was concluded that the VDP of the poplar boards was closely related with the press pressure. Increasing of the press pressure resulted in an enhanced peak density and mean density values, which are the defining factors of VDP.

The results obtained in this study revealed that the Janka hardness values of the poplar wood boards were improved with the increase of the press pressure. The surface hardness values were positively affected by the densification that occurred on the surface layers of the poplar wood boards. The boards pressed at press pressure of $2 \mathrm{MPa}$ and press temperature of $150^{\circ} \mathrm{C}$ had the highest hardness values.

It could also be concluded that surface hardness of wood materials from fast growing and low-value species could be improved by the thermal compression process. Thus, value added wood products could be produced with a wider range of use.

\section{Acknowledgements - Zahvala}

The authors thank Istanbul University Research Fund for its financial support in this study. The authors would also like to express their appreciation to Kastamonu Integrated Wood Industry and Trade Inc., Ko- 
caeli, Turkey for their assistance and Kerem Salih Colak, Huseyin Basri Bayirli and Osman Zafer Kaya, who are former undergraduate students at the Department of Forest Products Engineering at the Istanbul University, for their valuable help during the testing procedure. This article is an extension and continuation of the study presented at the ICWSE 2011 Conference.

\section{REFERENCES}

\section{LITERATURA}

1. Abraham, J.; Nemeth, R.; Molnar, S., 2010: Thermomechanical densification of Pannonia Poplar. In: Proceedings of the final conference of COST Action E53: 'Quality control for wood \& wood products' 4-7th May 2010, Edinburgh. 2010.05.04-2010.05.10. pp. 282-292. http://www.coste53.net/downloads/Edinburgh/ Edinburgh-Presentation/44.pdf.

2. ASTM-D 1037, 1999: Standard Test Methods for Evaluating Properties of Wood-Base Fiber and Particle Panel Materials, American Society for Testing and Materials, West Conshohocken, PA.

3. Burmester, A., 1973: Effect of heat-pressure-treatment of semi-dry wood on its dimensional stability. Holz Roh Werkst. 31, 237-243.

http://dx.doi.org/10.1007/BF02607268

4. Candan, Z., 2007: Effects of some production parameters on vertical density profile (VDP) and technological properties of medium density fiberboard (MDF). MSc Thesis, 400 p., Istanbul University, Istanbul, Turkey.

5. Candan, Z.; Hiziroglu, S.; McDonald, A.G., 2010: Surface quality of thermally compressed Douglas fir veneer. Mater. Des. 31, 3574-3577. http://dx.doi.org/10.1016/j.matdes.2010.02.003

6. Candan, Z.; Korkut, S.; Unsal, O., 2013: Effect of thermal modification by hot pressing on performance properties of paulownia wood boards. Ind. Crop. Prod. (In Press). http://dx.doi.org/10.1016/j.indcrop.2012.12.024

7. Dogu, D.; Tirak, K.; Candan, Z.; Unsal, O., 2010: Anatomical investigation of thermally compressed wood panels, BioRes. 5(4), 2640-2663.

8. Esteves, B.; Marques, A.V.; Domingos, I.; Pereira, H., 2007: Influence of steam heating on the properties of pine (Pinus pinaster) and eucalypt (Eucalyptus globulus) wood. Wood Sci. Technol. 42 (3), 193-207. http://dx.doi.org/10.1007/s00226-006-0099-0

9. Giebeler, E., 1983: Dimensional stabilization of wood by moisture-heat-pressure-treatment. Holz Roh Werkst. 41, 87-94. http://dx.doi.org/10.1007/BF02608498

10. Kamke, F.A.; Casey, L.J., 1988: Fundamentals of flakeboard manufacture: Internal - mat conditions. Forest Prod J. 38 (6), 38-44.

11. Korkut, S.; Kocaefe, D., 2009: Effect of heat treatment on wood properties. Duzce Univ. J. Forest. 5(2), 11-34.

12. Militz, H., 2002: Thermal treatment of wood: European processes and their background. IRG/WP 02-40241.

13. Seborg, R. M.; Millett, M. A.; Stamm, A. J., 1945: Heat - stabilized compressed wood (Staypak). Mech. Eng. 67, 25-31.

14. Sevim Korkut, D.; Korkut, S.; Bekar, I.; Budakci, M.; Dilik, T.; Cakicier, N., 2008: The effects of heat treatment on physical properties and surface roughness of Turkish Hazel (Corylus colurna L.) wood. International Journal of Molecular Sciences (IJMS) 9(9), 1772-1783. http://dx.doi.org/10.3390/ijms9091772
15. Stamm, A.J., 1964: Wood and cellulose science. Ronald Press, New York, USA.

16. Stamm, A.J.; Haris, E.E., 1953: Chemical processing of wood. Chemical Publishing Co., Inc, New York, USA.

17. Strickler, M.D., 1959: Effect of press cycle and moisture content on properties of Douglas fir flakeboard. Forest Prod. J. 9 (7), 203-215.

18. Tarkow, H.; Seborg, R.M., 1968: Surface densification of wood. Forest Prod. J. 18 (9), 104-107.

19. Tjeerdsma, B.F., 2006: Heat treatment of wood-thermal modification. SHR Timber Research, Wageningen, The Netherlands.

20. TS 2471, 1976: Wood, determination of moisture content for physical and mechanical tests. TSE (Turkish Standard Institution), Ankara, Turkey.

21. Unsal, O.; Candan, Z., 2007: Effects of press pressure and temperature on the moisture content, vertical density profile and janka hardness of pine wood panels. In: Proceedings of 10th International IUFRO Division - 5, Wood Drying Conference, August 26-30, 2007, Orono, Maine, USA.

22. Unsal, O.; Candan, Z., 2008: Moisture content, vertical density profile and janka hardness of thermally compressed pine wood panels as a function of press pressure and temperature. Drying Technol. 26, 1165-1169. http://dx.doi.org/10.1080/07373930802266306

23. Unsal, O.; Kartal, S.N.; Candan, Z.; Arango, R.A.; Clausen, C.A.; Green, F., 2009: Decay and termite resistance, water absorption and swelling of thermally compressed wood panels. Int. Biodeter. Biodegr. 63(5), 548552. http://dx.doi.org/10.1016/j.ibiod.2009.02.001

24. Unsal, O.; Candan, Z.; Korkut, S., 2011a: Wettability and roughness characteristics of modified wood boards using a hot-press. Ind. Crop. Prod. 34(3), 1455-1457. http://dx.doi.org/10.1016/j.indcrop.2011.04.024

25. Unsal, O.; Candan, Z.; Buyuksari, U.; Korkut, S.; Chang, Y.S; Yeo, H., 2011b: Effect of thermal compression treatment on the surface hardness, vertical density profile, thickness swelling of eucalyptus wood boards by hotpressing. J. Korean Wood Sci. Technol. 39(2), 148-155. http://dx.doi.org/10.5658/WOOD.2011.39.2.148

26. Wang, J.Y.; Zhao, G.J.; Iida, I., 2000: Effect of oxidation on heat fixation of compressed wood of China fir. Forestry Studies in China, 2 (1), 73-79.

27. Wang, J.; Cooper, P.A., 2004: Vertical density profiles in thermally compressed balsam fir wood. Forest Prod. J. 55 (5), 65-68.

28. Wang, J.; Cooper, P.A., 2005: Effect of grain orientation and surface wetting on vertical density profiles of thermally compressed fir and spruce. Holz Roh. Werkst. 63, 397-402. http://dx.doi.org/10.1007/s00107-005-0034-3

29. Wang, S.; Winistorfer, P.M., 2000: Fundamentals of vertical density profile formation in wood composites, Part 2. Methodology of vertical density formation under dynamic condition, Wood Fiber Sci. 32 (3), 220-238.

\section{Corresponding address:}

\section{Prof. SULEYMAN KORKUT}

Department of Forest Products Engineering

Duzce University

81620 Duzce-TURKEY

e-mail: suleymankorkut@duzce.edu.tr 